\title{
Valuing Environmental Benefit Streams in the Dryland Ecosystems of Sub-Saharan Africa
}

\author{
Caroline King-Okumu ${ }^{1,2}$ (1) \\ 1 The Borders Institute (TBI), PO Box 13385-00100 Nairobi, Kenya; caroking@yahoo.com \\ 2 GeoData Institute, University of Southampton, Southampton SO17 1BJ, UK
}

Received: 14 October 2018; Accepted: 10 November 2018; Published: 19 November 2018

\begin{abstract}
Policy-makers and practitioners often struggle or fail to define and quantify the economic impacts that can be achieved through ecologically sustainable investments in dryland ecosystems. This paper reviews the current state of the art in the characterization and valuation of environmental benefits in drought-prone areas of Sub-Saharan Africa. Benefit streams from ecosystem services associated with the production of food, energy and water are characterized, as well as those from supporting and regulating hydrological systems. For each value type, valuation approaches and examples of their application in Sub-Saharan African contexts are presented. The review is drawn from a series of recent methodological discussions, working papers and field research reports focusing on the benefits of locally determined and ecosystem-based adaptations under dryland climate extremes. The focus is on the challenges faced by practitioners and researchers tasked with developing benefit-cost assessments for investments in the adaptive management and conservation of dryland ecosystems, particularly in marginalized dry and drought-prone areas of Sub-Saharan Africa. Recommendations could also interest a wider global community of dryland researchers and development practitioners.
\end{abstract}

Keywords: ecosystem services; economic valuation; drylands

\section{Introduction}

Policy-makers and practitioners often struggle or fail to define and quantify the impacts that development projects can have on dryland ecosystems. There is a lack of baseline assessments of benefit streams from dryland ecosystems against which to compare new management alternatives. This is because economic evaluation of the returns on the existing investments in adaptive management and conservation of the dryland ecosystems have been rare and limited. However, interest in the challenges associated with such assessments is building in Sub-Saharan Africa and in many other parts of the world [1-4].

In this paper, the current state of the art in the identification and valuation of selected key environmental benefit streams in the drought-prone dryland regions of Sub-Saharan Africa is reviewed. Insights on questions currently faced by researchers and practitioners developing benefit-cost calculations and economic impact assessments are drawn from a series of recent working papers and field research reports focusing on economic assessment of the benefits from ecosystem-based adaptations in the dry areas of East and West Africa. These are contextualised within the broader available published literature from across the region.

The selection and presentation of material responds to concerns expressed by practitioners tasked with presenting economic assessments of the anticipated returns on investments in dryland restoration, climate change adaptation, and disaster preparedness projects in the drylands of Sub-Saharan Africa. The same practitioners are often also tasked to design monitoring and evaluation systems that could verify these projections in the event that project proposals are funded. 
The intention of the paper is that it should provide a useful and accessible reference source for project managers, practitioners and researchers developing benefit-cost assessments of small-scale adaptation and resilience-building interventions for environmentally sustainable management in the drylands, particularly in marginalized dry and drought-prone areas of Sub-Saharan Africa. This could be of interest to a wider global community of dryland researchers and practitioners as well. The primary question for the international scientific community is: what are the existing and potential benefits from adaptive management of the dryland ecosystems? [5-7]. This is particularly important where there are proposals to transform, replace or simply remove these under-recognized benefits through development initiatives. Since such proposals will introduce changes and tradeoffs among different benefit streams, there is an urgent need to identify and value the baseline values and potential for adaptive management.

Following a brief conceptual overview of the assessment challenge in the dryland ecosystems in Section 2, key ecosystem services are summarized. Methods used to generate this review are described in Section 3. Section 4 then presents the techniques and methods that are available to practitioners for the assessment and valuation of benefit streams that may be anticipated from adaptive management and conservation of the dryland ecosystems. The section is structured around four key benefit streams and includes case studies sourced from published assessments from Sub-Saharan Africa, both West and East. In addition to describing techniques for valuing the benefit streams, practical examples demonstrate how these can be connected to some of the many available approaches and scientific tools for quantification of the benefit streams.

The discussion, recommendations and conclusion in Sections 5 and 6 underline the opportunity and feasibility for practitioners to apply the available assessment methods. Synergies between the benefit streams that may not be quantified, but will merit additional attention following the valuation are also highlighted.

\section{Overview of the Challenge to Assess the Benefit Streams and Management Options in Dryland Systems}

\subsection{Adaptive Management in the Dryland Ecosystems}

Resource-dependent populations living in dryland ecosystems use their accumulated knowledge of environmental conditions and climatic patterns to adapt practices for managing shared or common pool resources [8-11]. These practices and adaptations enable communities to sustain their land and water resources for the long term while also drawing benefits from them in the short term. In cases where well-informed practices ensure that dryland ecosystems can retain and enhance their own endogenous production of goods and services, this reduces dependence on external cooperation and aid in the forms of disaster relief and social assistance [12-14]. Recognizing, maximizing and restoring ecosystem function, self-regulation and resilience can play an important role in ensuring that growth can be self-sustaining both for the ecosystem and for the current members of society.

The international community considers investments that it could make to boost adaptive resource management practices in relation to its current priorities and commitments for sustainable land management (SLM) [15], enabling community-based adaptations to climate change and variability [16], building resilience to drought by supporting adaptations that are considered to be ecosystem-based [17-19] or nature-based [20] (see example of common community-scale practices for adaptive management in Appendix A, Box A1). However, to establish the economic value of the endogenous productivity of the drylands and the business case for how it could best be improved requires baselines, data and models. These remain rudimentary and/or unavailable in many of the dryland production systems of Sub-Saharan Africa and elsewhere.

The economics of adaptation and returns on adaptation investments have received significant attention [1,3,21-27] (www.aboutvalues.net). But the economic value of returns on these investments remains challenging for practitioners to quantify and monitor systematically-especially under erratic, uncertain and drought-prone conditions that commonly occur in Sub-Saharan Africa [13,14,28-33]. 
There has not previously been a review that focuses on bringing together assessment methods and examples applied in both East and West Africa and presenting them in a way that could be convenient for practitioners from these regions.

\subsection{Identifying the Major Benefit Streams from the Dryland Ecosystems}

Economically valuable public goods and services provided by ecosystems in the drylands (as described in [34]) include water, energy and other essential provision services (Figure 1). These are supported and regulated by other services that sustain the system and its functions.

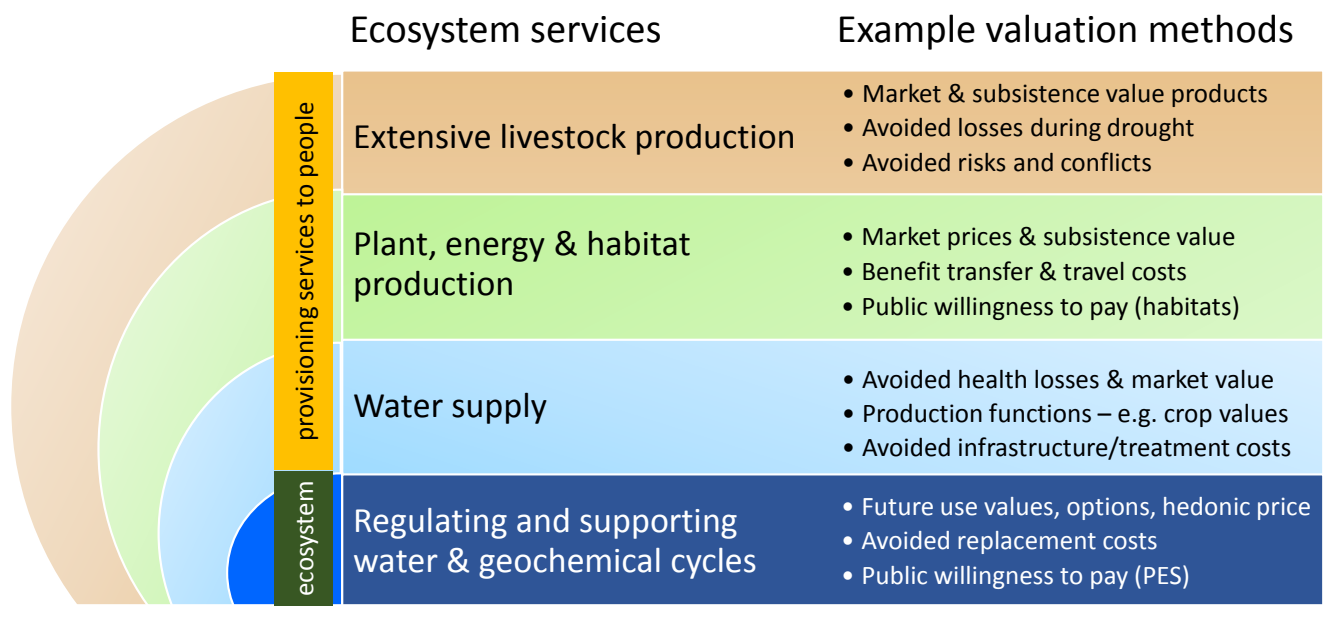

Figure 1. Goods and services in dryland ecosystems.

In dry and drought-prone environments, hydrology and climatic extremes can have a particularly strong influence over the functioning of the ecosystems and their productivity. When human populations are not able to manage these effects, natural hazards such as droughts can have disastrous effects on ecosystem services that support the well-being of dependent populations. In light of this, the analysis of benefit streams that is presented in this paper includes consideration of the economic value both of the provisioning services and also the essential underlying supporting and regulating services. This is a departure from the approach taken by many of the current available assessments which have not assigned a value to the supporting and regulating services for fear of double-counting the value of provisioning services (e.g., [35]).

Ecosystem accounting is an emerging field that aims to provide a consistent approach to analyzing environment-economy interactions [36-38]. But for most of the dry areas of Sub-Saharan Africa, this is still in its very early stages. Across Sub-Saharan Africa, assessing economic productivity is complicated by the nature of dryland products and services requiring valuation and the presence of various informal, undocumented economies. Often, national statistical systems fail to effectively record the productivity of goods and services from dryland systems that are highly relevant to livelihoods and the economy-including many of the products from extensive livestock raising, natural heat, energy sources, underground water storage and other environmental services.

Rather than insisting on monetizing all benefits and adding them together, a well-recognized alternative is to use a multi-criteria analysis. This weighs benefits expressed in diverse units that are not directly comparable either instead of or alongside the economic valuation of tradeoffs and can accommodate graduated values derived from subjective qualitative assessments, if necessary. In Botswana, multi-criteria decision analysis has been explored as a means to capture the breadth of benefits from communal grazing systems [39-41].

Economic valuation is helpful to weigh tradeoffs between some of the multiple effects caused by different investments-whereby one effect may cancel out the benefit of another. For example, a drip irrigation scheme may save water on a per hectare basis, as compared to a gravity-controlled 
system. But if the introduction of such systems causes a larger area to be irrigated-then the tradeoff between volume and extent of irrigation may mean that the adaptation does not achieve any overall water-saving at all. Economic assessment provides a means to place a comparable value on the effects on water versus food production. Other tradeoffs can be harder to weigh up-especially in multi-criteria analyses. For example, if a grazing system generates less income overall, but contributes in small ways to the well-being of a greater number of low-income households, opinions may differ concerning whether or not the tradeoff is worthwhile.

The scarcity or availability of goods and services is often driven by contextual processes operating at scales that are larger than the intervention areas of development projects within which economic assessments may be proposed. For example, pastures and wildlife habitats require landscape-level assessments, and water scarcity will also be affected by basin level processes and demands. Timescales for assessment of the value of benefits from investments in resource management also do not always match well to project and assessment timeframes. Where benefits are anticipated to accrue in the distant future, these anticipated benefits may be considered to have a net present value, but this is usually discounted because benefits that may arrive in the future are generally considered less attractive than benefits secured in the present [42].

\subsection{Assigning Value}

Research on the monetary valuation of natural resources dates back to the early 1960s but has progressively received wider attention through growing discussion of the capital and service values provided by nature and ecosystems [43]. An inherent challenge in any attempt to place an economic value on public goods and services is that different people will make different judgements about what to value, and how much it is worth. Local resource users' views of what should be valued can differ considerably from those of national or international agencies and partners. This is important because an economic assessment of returns on investments should focus on returns to society as a whole (which is different from a financial assessment of returns on investments to private individuals) [42].

Valuation methods for the benefit streams from dryland ecosystems can include market- and non-market-based approaches [3,44-46]. Ten broad types of valuation methods have previously been identified for the valuation of ecosystem services globally, but few of the cases identified were located in Sub-Saharan Africa [46] (Table 1). The 10 methods include use of available market values for ecosystem goods and services, or the costs that would need to paid to obtain them. Where there are no markets to buy the ecosystem goods and services, willingness to pay for access to them may suggest that such markets or payment systems could be created.

Table 1. Classification of ecosystem service valuation methods [46].

\begin{tabular}{|c|c|c|c|}
\hline \multicolumn{2}{|c|}{ Type } & Name of Method & Acronym \\
\hline \multirow{3}{*}{\multicolumn{2}{|c|}{ Market-based }} & Direct Market Pricing & DMP \\
\hline & & Payment for Ecosystem Services & PES * \\
\hline & & Factor Income/Production Function & $\mathrm{FI} / \mathrm{PF}$ \\
\hline \multirow{3}{*}{\multicolumn{2}{|c|}{ Cost-based }} & Avoided Cost & $\mathrm{AC}$ \\
\hline & & Mitigation and Restoration Cost & $\mathrm{MC} / \mathrm{RC}$ \\
\hline & & Replacement Cost & $\mathrm{RC}$ \\
\hline \multirow{4}{*}{ Willingness to pay (WTP) } & \multirow{2}{*}{ Revealed preference } & Hedonic Pricing & $\mathrm{HP}$ \\
\hline & & Travel Cost & $\mathrm{TC}$ \\
\hline & \multirow{2}{*}{ Stated preference } & Contingent Valuation & $\mathrm{CV}$ \\
\hline & & Group Valuation & GV \\
\hline
\end{tabular}

* A PES can be seen as an expressed WTP through the market. 
Provisioning services are most often valued through direct market pricing methods. However, there are also other alternatives where market prices do not fully reflect their value (see direct use values in [44]) (Figure 1). For habitat services, for example, methods such as factor income and contingent valuation are often used as an alternative to direct market pricing if these are not considered adequate [46]. Valuations of regulating services often use avoided cost and replacement cost methods in addition to direct market prices, where available (see description of indirect use values in [44]).

\section{Materials and Methods}

To identify some of the key benefit streams in the dryland systems of Sub-Saharan Africa and methods that can and have been applied to assess their economic value, this review draws on insights and examples from a series of recent working papers and field research reports focusing on economic assessment of the benefits from ecosystem-based adaptations in the dry areas of East and West Africa [47-52]. A series of meetings were held with planners and NGO staff implementing, monitoring and evaluating investments in shared resource management systems in a range of dry areas of Kenya, Senegal and Mali, as described in the respective project reports.

Findings were shared and discussed with practitioners tasked with the challenge to present economic assessments of the anticipated returns on proposed future investments in dryland restoration, climate change adaptation and disaster preparedness projects in the drylands of sub-Saharan Africa [53,54]. Practitioners highlighted the challenges to prepare a business case for such investments and referred to available examples of project proposals that have previously been approved by financing institutions including the Green Climate Fund (see: https:/ / www.greenclimate.fund/whatwe-do/projects-programmes). Additional relevant assessment challenges were identified through a broader overview of the nature of benefits that project managers and practitioners would wish to capture in their assessments as compiled for the World Overview of Conservation Approaches and Technologies (WOCAT) (see: https:/ /www.wocat.net/en/).

Having identified the practical challenges, and methods available in context at selected locations in Sub-Saharan Africa, further reviews of the available published literature across a wider geographical area of the region's drylands were made using keyword searches in SCOPUS online database. The keyword searches were filtered to select materials referring directly to cases in Sub-Saharan Africa. These could be used and further developed by practitioners and researchers who are working or studying there.

\section{Assessing and Valuing Benefit Streams}

\subsection{Livestock Production in the Drylands}

The production of livestock is the most widespread and traditional economic activity in the more arid regions of Sub-Saharan Africa $[55,56]$. Therefore, it is one of the most critical benefit streams for the societies that live in these regions. In addition to cows, sheep, goats, camels, etc., livestock production in the drylands may also include the keeping of poultry, rabbits, and bee-keeping for honey [35,57]. Livestock production can include production of live animals for sale, meat, milk, dung, skins and other products. Sometimes livestock also produce other services, such as draught power from donkeys, horses and camels, pollination from bees—or others. Increasingly, wildlife services are also attracting attention in the drylands of Sub-Saharan Africa.

Valuation of livestock and their services is usually dependent on market prices. Often, local or national statistics will be available on some-but generally not all—aspects of livestock production in the drylands of Sub-Saharan Africa (e.g., as in [58] for Senegal). Milk has a particular value in the diets and cultural traditions of pastoral communities of both East and West Africa [59,60], and is a growth industry [61-65]. Where livestock products such as milk are consumed for subsistence, statistics may not be available, but the volumes of production can still often be estimated, based on knowledge of 
herd size and lactation patterns (as demonstrated in Mopti, Mali, by [52], in Niger by [66],and in Kenya by $[67,68])$.

Resource economists use bioeconomic models to assess productivity in the rangeland ecosystems and the potential impacts of altered water and fodder availability [69-73]. Such models have been explored in drought-prone Sub-Saharan environments in the Senegalese Ferlo (see Box 1) [74], Niger [66], Ethiopia [75,76] and Kenya [77]. They require information on the relationships between herd size, lactation and reproduction rates, as well as animal nutrition and health (for further discussion of these in the context of the arid lands of Kenya, see: [67,78]).

Grass grown for fodder is one of the best documented successful investments to increase and maintain income and reduce vulnerable households' expenditures in the most drought-prone regions of Somalia, Ethiopia and Kenya [14]. Not only does improved forage availability directly affect the availability of milk and improve nutrition levels in vulnerable households (as described above), but it does so quickly - which can be important for project stakeholders. Because it grows rapidly, grass can give a positive return within a short space of time, and can continue to provide an economically valuable crop twice per year [79]. In light of this, it is attractive to households and agencies seeking to secure immediate livelihood improvements under drought conditions. A recent study has identified the economic value of animal feeding during droughts in terms of avoided emergency food relief supplies to drought-affected households [80]. Furthermore, in pastoral and agro-pastoral areas where most households keep livestock, fodder availability reduces animal malnutrition that can otherwise cause the loss of these assets during droughts.

A recent global assessment [4] has identified an estimated return on investment in grassland restoration of 35:1 over a twenty year period across the drylands and other climatological zones [81]. However, the bioeconomic models that are available to capture economic benefits from rangeland livestock production are only as good as the underlying datasets and field observations that they use. Where there is institutional support in place, they can be complemented by long-term field monitoring and measurements, as has been done to study the effects of enclosures in Kenya [82]. These can be verified using rapid participatory methods described above (e.g., [83,84]). Where support for these methods is not available, economic assessments can be based on input values drawn from the best available literature.

In extensive rangeland systems, physical inputs may be few, but institutional investments are still needed to coordinate communal land and water management systems [85]. Often these necessary investments and transaction costs are overlooked in assessments of the economics of pastoral livestock production. Also, in extensive systems, during the dry seasons and the droughts, transhumant livestock migrations occur. These are challenging to model effectively. The costs of livestock production increase during these times due to water shortages and pressures on grazing resources, conflicts and others. Climatic factors can aggravate increased risks of diseases and threaten the value of livestock production. A theoretical model of the economic connection between communal grazing, disease transmission risk, risk perceptions, and antimicrobial use has been developed and tested in Kenya [86]. The analysis supported by this model suggested that factors influencing subjective perception of disease risk and antimicrobial uses included disease history, and types of grazing systems-with greater levels of concern regarding disease prevalent in communal grazing systems, as compared to private grazing areas.

With intensification of the commercialization of livestock production, production models become more complex, and farmers no longer depend only on pastures to nourish their animals. Increasingly, they manufacture or buy supplements and they also often pay for water, labor and medical attention for their animals. Increasingly, livestock water productivity has gained attention in Sub-Saharan Africa $[87,88]$. The global average water footprint for beef produced from grazing systems is $243 \mathrm{~m}^{3} /$ ton for grey water and $465 \mathrm{~m}^{3} /$ ton for freshwater, whereas for industrial beef systems this average increases to 712 and 683 respectively [89]. Livestock raised in the extensive grazing systems across much of 
Sub-Saharan Africa often consume less water than those raised in other grazing systems because in the extensive systems they do not necessarily have access to water every day.

Some products from livestock, such as leather and wool, require significant amounts of processing to add value before they can be marketed as textiles, garments and furnishings. This is mediated by market access, and other conditions. A key methodological question for the valuation of rangeland productivity concerns the addition of value through value chains, and the extent to which the economic assessment is able to consider the dispersal of benefits and positive feedbacks along the value chain [90]. It has been argued that economic multipliers can be applied to represent the value of cash circulating through the regional economies in the drought-prone regions of Kenya and Ethiopia [91,92].

Box 1. Case Study: Valuing rangeland production in the Senegalese Ferlo using a bioeconomic model (based on Hein et al. [74]).

The anticipated effects of climate change in Senegal on the economic value of rangeland production were assessed by Hein et al. [74]. The assessment used an ecological-economic modelling approach. This enabled simulation of the effects of climatic changes and management responses via modifications of the stocking rates. The model was based on local data collected over a 10-year period (1981-1990) at the Widou Thiengoly research station in the western part of the Ferlo on vegetation production under different grazing densities and rainfall conditions. The model is a dynamic systems model, running with time increments of 1 year. The model calculates the annual income for the pastoralists as a function of annual rainfall and the long-term stocking rate maintained by the pastoralists. The model is spatially homogeneous, and changes in livestock routes or other adaptation strategies not involving changes in stocking densities are not considered.

For Senegalese pastoralists, the main source of income is the sale of animals for meat, with milk production coming in second place. The role of milk production and agriculture has decreased in the last decades with the increased focus on livestock herding for meat production. For reasons of simplicity, in the model it is assumed that income is only derived from the sale of animals. Income depends upon the amount of surplus livestock that can be sold annually on the market, as well as on the livestock price.

In years of drought, when there is not enough grass production to feed the livestock number corresponding to the long-term stocking rate, it is assumed that the pastoralists maintain the amount of livestock that can be fed, and that they sell the surplus on the market. However, the price will be low, as there will be a high supply, and low demand on the local markets. If a dry year is followed by a wet year, the pastoralists will purchase livestock in the market in order to stock up to the long-term stocking rate. If rainfall decreases, the optimal stocking density is reduced, and so are the maximum profits the pastoralists can obtain. Pastoralists can adapt to climate change by destocking, which would increase the societal profits gained per livestock unit as well as the overall profits compared to the current grazing strategy.

As the pastoralists maintain an open-access individual profit maximization strategy, the optimal rate of destocking is not expected to occur. But reductions in stocking rates are anticipated to result from predicted climatic changes due to reduced availability of fodder. The model does not allow analysis of consequent changes in the local labor markets (this would require a general circulation model). However, Hein et al. [74] concluded that climatic changes leading to a reduction in livestock numbers would result in reduced employment opportunities in the Ferlo and create further pressure on local resources.

\subsection{Energy, Plants and Habitat Production}

In the dryland systems, where sufficient water is available, solar energy is rapidly converted to net primary production, providing valuable plant products and habitats. Plant production can include wild or cultivated plants for use by humans (e.g., as food, medicines, and other non-timber forest products) or for the habitat and amenities that they provide collectively in situ (e.g., as described in [93]). These are in addition to supporting animal production (see previous section). Often, plant and energy production can be valued using market prices. However, due to value-adding processes for energy, food and other products, production functions may reveal higher values than the available market prices for the raw material.

Valuation of wild plant products is often challenging due to lack of statistical information. In some cases, annual inventories of the value of the non-wood products from the forests and also the revenues gained from permits and taxes, etc., may also be available (e.g., [94] for Senegal). It can be possible to obtain information on agricultural crop production and prices through the national statistical systems (e.g., [58] for Senegal, or [95] for Kenya]. Where information about plant products and their value 
is not complete, or not available at a suitable scale, rapid appraisal techniques are frequently used to obtain relevant information, when required (see e.g., Box 2).There are also many modeling tools available and applied for understanding the production of crops in the sub-Saharan agroecosystems (see e.g., [96] in West Africa, [97-99] in East Africa).

Across sub-Saharan Africa, the amounts of energy consumed from different sources including wood-fuels for cooking and others are calculated in the national emissions inventories based on population numbers and assumptions concerning the locally available fuel sources. For example, in Kenya, it is estimated that $50 \%$ of households depend on charcoal and one person uses about $1.9 \mathrm{~kg}$ of charcoal a day [100]. The majority of producers do not have tree-replanting schemes. They also use wet wood in earth mould kilns to convert wood to charcoal. This produces a low conversion of solar energy and woody biomass to charcoal. Increasing the conversion efficiency would increase fuel value achieved per volumetric unit of wood, as well as reducing pollution and habitat degradation where wood is over-harvested (see [101]). As yet, direct use of solar energy without conversion to biomass is still relatively limited in Sub-Saharan Africa. The use of fossil fuels from within the region is also not yet widespread-although often such fuels are imported.

At present, charcoal-burning is often practiced as an income-generating strategy and can be one of the few available sources of income for households in Sub-Saharan dryland ecosystems either alongside livestock-raising or as a substitute for households who do not have access to livestock. Charcoal can be sold and transported to supply urban households with fuel. In Kenya, use of charcoal in urban areas has risen by $64 \%$ in two decades [102]. The charcoal industry is estimated to employ 500,000 people and generate more than US $\$ 27$ million that benefits grassroots communities. Yet it remains illegal and is not captured in national statistics or fiscal systems.

Where communities produce crops for subsistence uses, available statistics may be incomplete and provide an inadequate indication of their economic value. Market gardening production-which can generate numerous harvests throughout the year may also not be well-captured in national statistical systems. Irrigated market gardening can generate significant contributions to household income in marginal dry areas and is a popular investment choice for development projects in many parts of Sub-Saharan Africa (see e.g., an economic assessment in the Volta Basin [103]).

Where plants have been cultivated, there will be input costs including labor and others that must be weighed against the output value of the crop. If the inputs are subsidized, the economic costs to society will be higher than the financial costs paid by individual farmers. There may also be opportunity costs to society associated with inputs such as water or conversions of land-use-even if these are not considered to have a high market value. Examples include irrigation schemes constructed in the East African pastoral rangelands [104-106]. Also in northern Nigeria [107-110], the Inner Niger delta in Mali [111-114] and parts of Mauritania [115,116]. A recent study in the arid lands of Kenya [48] demonstrated that irrigated agriculture could generate a value of US $\$ 0-4$ per unit of water applied, whereas extensive production could generate US $\$ 13-22$ and other domestic uses up to US\$90.

Output values for wood, charcoal and crops are usually identified in relation to market prices. Where there are no markets, benefit transfer is often proposed as a valuation method. Examples of cases where benefit transfer is frequently applied include medicinal plants, such as incense, that may have a high value in some markets, even if this value is not yet accessible to communities in many dryland areas. Some medicinal and aromatic plants require processing to extract high-value products, such as essential oils and dyes. This raises questions about real and hypothetical value chains, similar to those identified for livestock products. In addition, some of the use values of plants e.g., for medicines may not yet be fully understood and could require years of future research to uncover. It is very difficult to assess the cost to society if these plants are not conserved due to habitat loss and extinctions.

Plants, trees and natural fibers are used to generate agreeable habitats for humans, including shaded areas, cooler, well-ventilated buildings, fans, etc. They create cleaner air and reduce urban heat island effects. Bamboo, raffia and other fibres provide lightweight, portable and biodegradable furniture, ornaments and accessories that are aesthetically pleasing. Many relevant practices are 
well-known and widely available in vernacular building styles and traditional handicrafts. More are also continually evolving.

Beyond individual plant products, the value of plant assemblages and habitats for wildlife tend to be assessed based on wildlife tourism revenues, according to the travel cost method [42]. Sometimes, conservationists are willing to pay also through other arrangements-e.g., in eastern Africa, Maasai land owners whose grazing lands fall within the ecologically important Kitengela wildlife dispersal area in Kenya have entered into land leasing agreements with conservation groups who lease land from households in return for commitments to maintain the land unfenced and open to both wildlife and livestock [117-119].

Willingness to pay among the Nairobi public for securing the Kitengela wildlife dispersal area has been estimated at US\$1.2 million which could provide a longer-term source of financing [120]. In the Simanjiro district of Tanzania, a similar scheme has been established where tour companies make an annual payment of US $\$ 4500$ to communities to prevent agricultural encroachment onto a 23,000 -acre wildlife corridor [121].

Box 2. Case study: valuing energy, plant and habitat production in West African agroforestry using participatory rapid appraisal of social returns (based on Weston et al. [101]).

The anticipated effects of agroforestry and improved stoves on the economic value of energy and plant provisioning in the district of Talensi in the semi-arid Upper East Region in Ghana have been assessed by Weston et al. [101]. The assessment used focus groups and a household survey to generate a social return on investment analysis (after [122,123]), which identifies proxy financial values for non-market as well as market benefits.

This enabled valuation of a large number of benefits that were generated by the agroforestry interventions, including their asset value as wood resources that could be used or sold in difficult times. But also, until then, other benefits that they would provide in situ, including effects on the production of crops, livestock and wild foods. Crop production is boosted by the presence of trees and their effects on soil quality. Livestock production is increased by the availability of shade and fodder from the trees. Wild foods are either produced directly by the trees (fruits) or by the habitat that they provide e.g., for rabbits and partridges. The presence of the trees also creates other beneficial effects that were considered valuable by the human population, including shade, reduced windspeeds, airborne dust, aesthetic and cultural effects.

Weston et al. [101] used this information to calculate social returns over three time periods: immediately after close of project activities; 4 years after project; and 10 years after the project using a discount rate of $8.9 \%$ p.a., which was Ghana's predicted inflation rate for 2012-2017. The values for each social impact were added to further values associated with the presence of the project (such as increased credit, optimism and community solidarity), aggregated into a single total value and divided by the total cost of project inputs to arrive at a social return on investment ratio for each of three time periods.

\subsection{Water Availability and Supply}

Access to water is usually highly valued by society in water-stressed environments. This value provides for a range of uses by different groups and individuals-including for household needs, watering of livestock, market gardening and firefighting-even if sometimes these are free of charge [124].

Water supply often has a market value-paid to service-providers or vendors. Nevertheless, the costs that society pays to secure water supplies may often be much higher than the unit prices for the water on the local markets - which may sometimes be low or non-existent due to market inefficiencies, state support or subsidies. Market prices for water supply can also rise sharply in times of drought and scarcity. Because of this complication in drought-prone dryland areas, it is particularly problematic to rely on the use of market values to assess the benefits of improved water supplies.

Valuation of water supply in the drylands can include the avoided costs of disease [125-128] and replacement expenses such as travel costs to obtain water supplies $[129,130]$ or infrastructure, pumping and treatment costs. The input costs to society to secure water availability are very context-dependent and may be higher in remote or hard-to-reach areas than they are in densely populated areas. Furthermore, in addition to infrastructure, the costs of gaining water supplies must 
include investments in human capacities. These costs are often difficult to fully quantify or generalize. They are also context-specific and influenced by many other factors.

'Production-function' approaches to the valuation of water supplies focus on estimating how much value is added to the economy per unit of water supplied $[109,131]$. This can be relatively easily estimated for agricultural products where there is a market and the relationship of water inputs to outputs is reasonably well understood $[132,133]$. Production-functions for water can give values that are higher than the market prices for water due to value-adding processes. However, there are usually other inputs to production that may also need to be accounted for, in addition to the units of water.

There is often a hierarchy of different production values for water according to its various uses. Frequently, the most readily accessible value for water is the value of plant production that it can support (see previous section) (e.g., as in $[109,134]$ ). Normally, the value to society of a cubic metre of water for basic human needs should be greater than the value of a cubic metre of water to be used for irrigation.

The actual economic value of the productive uses of water will be sensitive to supply and demand factors affecting prices that are more difficult to understand and predict than the physical production aspects [57]. Often, households will use a combination of multiple water sources to support their needs and economic activities, and will change these configurations under different conditions of water scarcity $[109,135]$. As a result of this, measuring water's contribution to all sectors, and to the total value chain of a good or service, or its total economic benefit can also be complex [37,132,136-138].

Sometimes there is an opportunity cost for water supply if this may reduce its availability for other possible uses-e.g., where water is extracted in the upstream part of a basin and so becomes unavailable to other users downstream (see Box 3) [57]. Taking a catchment level approach to assessing the value of water availability can be particularly important to ensure that water is available for all vulnerable households' basic needs during droughts. Using infrastructure, water can be transferred across the system or catchment to be made available where it is most needed for particular uses at specific points in time.

Box 3. Case study: valuing water supply in a Kenyan rangeland using a water evaluation and planning model (based on Mutiga et al. [139] and Silvestri et al. [35]).

The anticipated effects of upstream water extraction in the Ewaso Ng'iro North Catchment, Kenya, on the economic value of ecosystem service provision across the catchment as a whole were assessed by Silvestri et al. [35] using market valuation methods to identify the values of provisioning services in the irrigated farmlands and rangelands. The study drew on exploratory work by Mutiga et al. [139], using a water evaluation and planning model (WEAP) ([140] see: www.weap21.org).

The economic value assigned to upstream irrigation extractions did not take into account the opportunity costs and externalities caused by the extraction of water from the system, which reduced its availability downstream during a period of severe drought. Losses and damage to livestock and livelihoods in the downstream rangelands were also not taken into consideration. In the valuation of services to downstream areas, livestock production was assigned a value that may have been underestimated. Furthermore, human domestic uses of water were not valued at all-neither upstream nor downstream. Based on this assessment, continued increases in upstream water use for irrigation could be justified in light of their apparently major contribution to the economy.

Subsequent studies suggested that reduced access to water supply for humans and livestock in downstream areas during droughts caused unsustainable losses of lives, assets and livelihoods, which in turn seriously affected the growth of the national economy [141]. Furthermore, the value of downstream livestock production and domestic water uses has increasingly gained in recognition $[48,142,143]$. These observations suggest that the rationale for continued upstream extractions should be re-evaluated in light of increased understanding of the resulting externalities downstream.

Although in these studies the WEAP was demonstrated to be a useful tool for modelling the physical aspects water allocation across the catchment, there is a critical need for careful selection of the assumptions and valuation methods to be assigned to the different water-use alternatives represented through the model. 


\subsection{Supporting and Regulating Services for the Functioning of the Dryland Ecosystems}

Critical supporting and regulating processes for the functioning of the dryland ecosystems can include regulation of water flows, flood defense, groundwater recharge, water purification, storage, and soil conservation, including for carbon sequestration (see Box 4). The value of the supporting services can be captured in terms of the avoidance of damage (e.g., for flood-prevention) and replacement costs to reproduce these services if they were not provided by nature (e.g., costs of infrastructure for pumping and treating water) $[44,144,145]$.

Various studies have explored public willingness to pay for ecosystem services that can be achieved through soil and water management, groundwater recharge and revegetation to sustain ecosystems (e.g., by regulating stream-flow and reducing flood risks) or to increase downstream water quality. For example, in South Africa, Turpie et al. [146] assessed public demand and willingness to pay for groundwater recharge, flood attenuation and flow regulation using a geographical information system. Due to water scarcity, they assumed that groundwater recharge was fully demanded and that therefore the entire public would be willing to pay for it, but that demand for flood attenuation should be adjusted by a demand factor applied at a secondary catchment scale. If urban areas or mines occurred within $100 \mathrm{~m}$ of rivers then the service was considered fully demanded, if irrigated agriculture was present, the service was considered $50 \%$ demanded, otherwise it was not considered to be demanded. Maps of households and their estimated willingness to pay were used to generate estimates of the economic value of the services to society.

For over a decade, researchers have been exploring scope for payments for watershed services in Kenya's Tana River catchment to avert downstream water shortages and treatment costs. Regulating runoff and preventing soil erosion upstream is expected to increase the quality of water downstream but farmers will not maintain these practices without sufficient economic incentives [147]. On the other hand, construction of dams upstream will reduce the availability of drinking water downstream $[148,149]$. Recently, a business case has been presented for a water fund through which a company that supplies water to Nairobi by diverting water from the Tana river can pay for upstream soil conservation [150-152]. The water fund agreed to provide payments to upstream tea and coffee farmers to regulate water flows, runoff and erosion by maintaining the upstream parts of the catchment. No payments will be made to the downstream users of the catchment whose supply is reduced but the Kenyan government is investing in a seawater desalination plant to boost downstream urban water supplies.

Other aspects of the economics of soil erosion control can involve on-site productivity and carbon sequestration [153]. International markets for payments for carbon sequestration services are increasingly becoming established through global initiatives to mitigate climate change. Such schemes have been explored in various parts of Africa. Some additional relevant valuation approaches include option values which have been used for valuation of rights to future services e.g., as they would for energy exploration. These have a market value and can be traded. No examples of trading in rights to water regulation and storage have been identified in Sub-Saharan Africa during the preparation of this review, but trading in water rights has been introduced in water scarce areas of North America and Australia [154]. Access to water affects the value of land in many parts of the world, including Sub-Saharan Africa [155]. A relevant valuation approach, known as hedonic pricing, focuses on capturing the difference in market value of properties with or without access to the service [156,157]. Such an approach has been applied in other parts of the world, e.g., to assess willingness to pay to avoid erosion and sedimentation of lakes and improve water quality [158,159] or flood risk [160]. Recently, this approach has been used to identify the value of reduced flood risks and other improvements to living conditions in African cities [161].

Where water storage in dry areas enables populations to reduce vulnerability to drought, this can be valued in terms of the avoided costs e.g., avoided reductions in livestock productivity and/or avoided mortalities $[28,141]$. However, sometimes the lack of proven counterfactual evidence reduces the credibility of claims of damages avoided. To assess the value of increases in water storage and 
availability-e.g., through increased groundwater recharge, the anticipated future use of the water can have a value.

Assessing the economics of groundwater management effects can require determination of an optimal extraction path for an aquifer over time. A spatial externality in which excessive pumping at one location on the aquifer lowers the water table at another location may also require attention [162-164]. Practical challenges for economic assessment of this and other effects on groundwater availability under different land management conditions include the problem that groundwater conditions and extraction rates are subject to strategic private management and information constraints $[165,166]$.

Box 4. Case study: assessing water regulation and carbon sequestration using InVEST model (based on: Sahle et al $[167,168]$ and others cited).

The anticipated effects on ecosystem service provision to be achieved through introducing agroforestry in the Wabe River catchment of the Gurage Mountain chain landscape, Ethiopia, over the period 2017-2030 have been modelled by Sahle et al $[167,168]$ using the InVEST model [169]. Under a future land-use scenario with increased agroforestry, improvements could include increased food production $(102 \%)$, water yields $(17 \%)$ and carbon sequestration (19\%), and reduced sediment export $(21 \%)$ and soil loss $(18 \%)$. Varying the extent of agroforestry activities would generate altered estimates, enabling assessment of tradeoffs among the different options. Quantified estimates of water yield and carbon sequestration generated using InVEST can be assigned economic values using market prices or other methods to facilitate the assessment of tradeoffs.

Water yield in InVEST is defined as the amount of water that runs off the landscape (precipitation minus storage and evapotranspiration losses) [170]. Limitations of InVEST include an annual timeframe, and also that surface and base flow partitioning and inter-annual water delivery timing are not captured so it cannot assess effects on groundwater recharge and all other estimates are insensitive to these critical processes in the dryland ecosystems [169]. This means that the model may be of limited use in assessing the effects of investments other than revegetation.

InVEST has proved useful for obtaining broad estimates of the effects on water yield based on limited input information where such information is not available to support other modelling tools-e.g., in the Nile Basin [171]. The InVEST model has also been applied in other areas of Sub-Saharan Africa, including Rwanda [172], Ghana, and Cote D'Ivoire [173].

Other hydrological modelling approaches that have been explored to generate assessments of effects of vegetation on hydrology, including flow regulation and storage that are more sensitive to variations in land surface conditions include the soil water assessment tool (SWAT) [145,151,174], among others (see e.g., [144]).

\section{Discussion}

Even though economic evaluation of ecosystem service benefit streams from the dryland ecosystems have been relatively rare and limited, a significant body of relevant examples is available in Sub-Saharan Africa, as identified in this review. These include assessments of critical benefit streams from ecosystem service values associated with water availability, energy, food, and the underlying ecosystem support functions. Increasingly, assessments are taking into consideration the value of water and energy resources-both as a supporting and regulating features in the drylands as well as essential commodities that contribute directly to human well-being.

Examples of assessments applied across the region demonstrate that it has already been possible for practitioners to assess the extent and economic value of some these benefit streams on a piecemeal basis, even if comprehensive long-term assessments have not yet been attempted. A range of adaptive management practices that affect these benefit streams are also identified. It is important to acknowledge that the selection of benefit streams considered in this review was not exhaustive and there can be many other benefit streams worthy of attention.

For the benefit streams considered, the compilation of examples that is presented in this review is also not exhaustive. Yet, the clear affirmation that the selected benefit streams can and have been valued in both West and East Africa should encourage practitioners that further such assessments are feasible. Collectively, the precedents and examples drawn together in this review demonstrate the 
potential for more systematic assessment of the current level of benefits from the dryland systems and of the scope for investments in further improving management practices.

This should encourage practitioners to continue to identify and value the baseline values of benefit streams from the existing management systems in the drylands and the potential for adaptive management. This will create a stronger business case for investment-both for donors and for local communities to reinvest.

Where effects on benefit streams are predicted at the outset of projects, it is important to recognize that not all investments succeed as planned (personal communication: Obadiah Mungai, 26 May 2018). Some investments can fail or may not secure the benefits that are anticipated. Therefore, careful monitoring ex-post assessment following the investment process is important. To build necessary institutions and capacities for these processes in order to support adaptive management may require additional investments in human capacities.

The diversity and layering of multiple benefits that dryland ecosystems provide can pose a practical challenge for assessment. Not just one but often a range of different types of goods and services are generated and can be affected by investments in local resource management in the drylands. For example, a water-harvesting investment can simultaneously generate all of the types of benefit streams described. So can an investment in agroforestry.

In most cases, some very important aspects of the benefits streams and adaptations will escape economic evaluation. The real costs of illnesses in terms of missed opportunities and conflicts in the communities are difficult to identify but the benefits from avoiding these problems are likely to be enormous. Where these are secured, the local institutions can also secure further benefits, such as increased confidence and capacities, and other changes in perceptions and social processes.

Synergies between benefits can introduce further complexity and often escape economic assessment. This problematizes the additive summation of benefits since, with synergies, the final sum-total of the benefits will be more than the combined value of the individual benefit streams. For example, rangeland restoration may improve the availability of fodder, milk and tree growth, while also enabling lactating livestock to stay closer to settlements. The end result of this will be of greater benefit to household than the sum of the value of the milk production and the reduced journey times for herding and wood-collecting because the households having access to free supplies of milk and fuel for cooking will have better diets, lower expenditures, and more time to engage in productive activities. These may enable households to multiply the benefits that they obtain.

There may also be cost-savings to the humanitarian and international development communities, national governments and society more broadly due to reduced vulnerability to droughts and floods and avoidance of the associated losses and damages.

\section{Recommendations and Conclusions}

The review has identified some key benefits from local investments in dryland ecosystems that are worthy of additional consideration because they are essential to the livelihoods of the local populations - such as the value of livestock production, water resources, energy in the forests, and others. We have also identified available methods to fill the strategic gaps in the available statistical systems. It is recommended that decisionmakers should choose the tools, systems and calculations that will best capture the value of their investments and the benefits that are most critical to society.

This paper has demonstrated that economic assessment of some of the returns on investments in dryland ecosystems is possible for project managers and researchers to undertake even at the early stages of the implementation of projects. Practical insights presented in the paper demonstrate that such assessments can at least include one or two benefits that will appear during the first year. In the exploration of the assessment process, it is likely that other benefits will be identified that will accumulate over the longer term and hence may be more challenging to assess. Wherever, possible, mainstreaming of systems to monitor and assess critical benefit streams into national statistical systems is strongly recommended. 
As decision-makers and practitioners increase their use of the available assessment methods to value the benefit streams that are generated in dryland ecosystems, this will improve the availability of baseline information. Improving the baselines will facilitate the assessment of potential impacts from investment alternatives. The wider global community of dryland researchers and development practitioners could accelerate the current state of the art in the assessment of benefits from investments in dryland ecosystems by building these institutional capacities to generate such assessments as well as through continued support for physical land and water management improvements both upstream and downstream in dryland ecosystems.

Funding: The preparation of this manuscript received no external funding.

Acknowledgments: In-kind support received from the following sources should be acknowledged: IUCN, KEFRI, WOCAT, IIED and the ADA Consortium, GIZ ELD Initiative, the University of Southampton and the Oxford Deserts Conference. None of the above bears any responsibility for the final content of the manuscript, including any errors or oversights that it may contain. The author also wishes to thank two anonymous reviewers and the editorial office for outstanding Editorial Assistance and support.

Conflicts of Interest: The author declares no conflict of interest

\section{Appendix A}

Box A1. Examples of community-scale practices and investments for adaptive management in dryland ecosystems.

To maximize services from livestock production:

- Increase fodder availability or introducing supplementary feeding;

- Improve watering facilities and transhumance routes and patterns in extensive systems enabling access to water and pasture during dry seasons and droughts;

- Improve veterinary facilities, vaccination and disease-reduction programmes.

To maximize services from plant production:

- Enclosure of vegetated areas to prevent over-grazing or extraction by humans;

- Water-harvesting and irrigation systems to prevent crop failure during droughts and enable more frequent harvests e.g., for market gardening;

- Improve storage facilities to prevent post-harvest losses due to floods and fires.

To maximize services from energy production:

- Improve conversion efficiencies of stoves and burners;

- Increase use of solar-powered systems for pumping and treatment of water;

- $\quad$ Establish mini-grids for distribution of renewable energy supplies to households.

To maximize services from water supply:

- Improve surface water pans, reservoirs and other water-harvesting structures;

- Deepen shallow wells and digging boreholes to accelerate access to groundwater reserves;

- Install and improve water supply and treatment networks.

To maximize supporting and regulating services:

- $\quad$ Soil and water management to prevent erosion and increase infiltration and groundwater storage and boost carbon sequestration;

- Revegetation-e.g., afforestation or construction of wetlands to improve soil quality, settle contaminants, increase infiltration and boost carbon sequestration;

- Institutional strengthening to manage the above and other practices, as needed. 


\section{References}

1. Chambwera, M.; Heal, G.; Dubeux, C.; Hallegatte, S.; Leclerc, L.; Markandya, A.; McCarl, B.A.; Mechler, R.; Neumann, E.J. Chapter 17: Economics of Adaptation. In Climate Change 2014: Impacts, Adaptation, and Vulnerability. Part A: Global and Sectoral Aspects. Contribution of Working Group II to the Fifth Assessment Report of the Intergovernmental Panel on Climate Change; Field, C.B., Barros, V.R., Dokken, D.J., Mach, K.J., Mastrandrea, M.D., Bilir, T.E., Chatterjee, M., Ebi, K.L., Estrada, Y.O., Genova, R.C., et al., Eds.; Cambridge University Press: Cambridge, UK; New York, NY, USA, 2014; p. 33.

2. Economics of Land Degradation Initiative (ELD); United Nations Environment Programme (UNEP). The Economics of Land Degradation in Africa: Benefits of Action Outweigh the Costs; Economics of Land Degradation Initiative: Bonn, Germany, 2015; p. 156.

3. Emerton, L. Valuing the Benefits, Costs and Impacts of Ecosystem-Based Adaptation Measures-A Sourcebook of Methods for Decision-Making; Deutsche Gesellschaft für Internationale Zusammenarbeit (GIZ) GmbH: Bonn, Germany, 2017; p. 288.

4. IPBES Secretariat. Chapters of the Thematic Assessment Report on Land Degradation and Restoration of the Intergovernmental Science-Policy Platform on Biodiversity and Ecosystem Services; IPBES Secretariat: Bonn, Germany, 2018.

5. United Nations Convention to Combat Desertification (UNCCCD). Global Land Outlook; UNCCD: Bonn, Germany, 2017; p. 340.

6. Davies, J. The Land in Drylands: Thriving in Uncertainty through Diversity; United Nations Convention to Combat Desertification (UNCCD): Bonn, Germany, 2017; p. 18.

7. Cohen, S. African Drylands Commodity Atlas; Secretariat of the United Nations Convention to Combat Desertification, the Common Fund for Commodities Intergovernmental Group on Grains of the United Nations Food and Agriculture Organization, International Crops Research Institute for the Semi-Arid Tropics: Bonn, Germany, 2009; p. 82.

8. O'Keefe, L.; Howes, M. A Select Annotated Bibliography: Indigenous Technical Knowledge in Development. IDS Bull. 1979, 10, 51-58. [CrossRef]

9. Brokensha, D.W.; Warren, D.M.; Werner, O. (Eds.) Indigenous Knowledge Systems and Development; University Press of America: Lanham, MD, USA, 1980; p. 466.

10. Warren, D.M. Using Indigenous Knowledge in Agricultural Development; World Bank: Washington, DC, USA, 1991; p. 58.

11. Villamor, G.B.; Badmos, B.K. Grazing game: A learning tool for adaptive management in response to climate variability in semiarid areas of Ghana. Ecol. Soc. 2016, 21, 39. [CrossRef]

12. Return on Investment for Emergency Preparedness Study; The Boston Consulting Group, World Food Programme (WFP)/The United Nations International Children's Emergency Fund (UNICEF): Boston, Germany, 2015; p. 35.

13. Bond, C.A.; Strong, A.; Burger, N.; Weilant, S.; Saya, U.; Chandra, A. Resilience Dividend Valuation Model Framework Development and Initial Case Studies; RAND Corporation: Santa Monica, CA, USA, 2017; p. 178.

14. Venton, C.C. Economics of Resilience to Drought; United States Agency for International Development (USAID): Washington, DC, USA, 2018; p. 43.

15. King, C. Sustainable Management of Marginal Drylands (SUMAMAD): Sharing Success Stories from Indigenous, Adaptive and Innovative Approaches. In The Future of Drylands; Lee, C., Schaaf, T., Eds.; Springer: Dordrecht, The Netherlands, 2008; pp. 747-761.

16. Reid, H. Ecosystem- and community-based adaptation: Learning from community-based natural resource management. Clim. Dev. 2016, 8, 4-9. [CrossRef]

17. Bertram, M.; Barrow, E.; Blackwood, K.; Rizvi, A.R.; Reid, H.; Scheliha-Dawid, S.V. Making Ecosystem-Based Adaptation Effective: A Framework for Defining Qualification Criteria and Quality Standard; International Institute for Environment and Development (IIED): London, UK; International Union for Conservation of Nature (IUCN): Gland, Switzerland, 2017; p. 14.

18. Vignola, R.; Locatelli, B.; Martinez, C.; Imbach, P. Ecosystem-based adaptation to climate change: What role for policy-makers, society and scientists? Mitig. Adapt. Strat. Glob. Chang. 2009, 14, 691-696. [CrossRef] 
19. Doswald, N.; Munroe, R.; Roe, D.; Giuliani, A.; Castelli, I.; Stephens, J.; Möller, I.; Spencer, T.; Vira, B.; Reid, H. Effectiveness of ecosystem-based approaches for adaptation: Review of the evidence-base. Clim. Dev. 2014, 6, 185-201. [CrossRef]

20. WWDR. The United Nations World Water Development Report 2018: Nature-Based Solutions for Water; United Nations World Water Assessment Programme/UN-Water/UNESCO: Paris, France, 2018; p. 154.

21. Trærup, S.; Stephan, J. Technologies for adaptation to climate change. Examples from the agricultural and water sectors in Lebanon. Clim. Chang. 2014, 131, 435-449. [CrossRef]

22. Economic Evaluation of Climate Change Adaptation Projects Approaches for the Agricultural Sector and Beyond; World Bank: Washington, DC, USA, 2010; p. 66.

23. Guidelines for the Economic Analysis of Projects; Asian Development Bank (ADB): Manilla, Philippines, 2017; p. 170.

24. Sartori, D.; Catalano, G.; Genco, M.; Pancotti, C.; Sirtori, E.; Vignetti, S.; Bo, C.D. Guide to Cost-Benefit Analysis of Investment Projects Economic Appraisal Tool for Cohesion Policy 2014-2020; European Commission: Brussels, Belgium, 2015; p. 364.

25. Watkiss, P.; Hunt, A.; Blyth, W.; Dyszynski, J. The use of new economic decision support tools for adaptation assessment: A review of methods and applications, towards guidance on applicability. Clim. Chang. 2015, 132, 401-416. [CrossRef]

26. The Economic Advantage: Assessing the Value of Climate Change Actions in Agriculture; International Fund for Agricultural Development (IFAD): Rome, Italy; International Center for Tropical Agriculture (CIAT): Cali, CO, USA; CGIAR Research Program on Climate Change, Agriculture and Food Security (CCAFS): Wageningen, The Netherlands, 2016; p. 8.

27. Vermeulen, S.; Richards, M.; Pinto, A.D.; Ferrarese, D.; Läderach, P.; Lan, L.; Luckert, M.; Mazzoli, E.; Plant, L.; Rinaldi, R.; et al. The Economic Advantage: Assessing the Value of Climate Change Actions in Agriculture: Economic Evidence from Research by IFAD, CGIAR and Partners; IFAD: Rome, Italy; CGIAR: Monpellier, France, 2016.

28. Venton, C.C.; Fitzgibbon, C.; Shitarek, T.; Coulter, L.; Dooley, O. The Economics of Early Response and Disaster Resilience: Lessons from Kenya and Ethiopia; Department for International Development (DFID): London, UK, 2012; p. 84.

29. Vardakoulias, O.; Nicholles, N. Managing Uncertainty: An Economic Evaluation of Community-Based Adaptation in Dakoro, Niger; New Economics Foundation, CARE: London, UK, 2014; p. 53.

30. Siedenburg, J. Community-Based Cost Benefit Analysis (CBCBA). Findings from DFID Kenya's Arid Lands Support Programme; Landell Mills: London, UK, 2016; p. 62.

31. Bond, C.A.; Strong, A.; Burger, N.; Weilant, A.S. Guide to the Resilience Dividend Model; RAND Corporation: Santa Monica, CA, USA, 2017; p. 43.

32. Shreve, C.M.; Kelman, I. Does mitigation save? Reviewing cost-benefit analyses of disaster risk reduction. Int. J. Disaster Risk Reduct. 2014, 10, 213-235. [CrossRef]

33. Logar, I.; van den Bergh, J.C.J.M. Methods to Assess Costs of Drought Damages and Policies for Drought Mitigation and Adaptation: Review and Recommendations. Water Resour. Manag. 2013, 27, 1707-1720. [CrossRef]

34. Adeel, Z.; Safriel, U.; Niemeijer, D.; White, R. Ecosystems and Human Well-Being: Desertification Synthesis: A Report of the Millennium Ecosystem Assessment; World Resources Institute: Washington, DC, USA, 2005; p. 36.

35. Silvestri, S.; Zaibet, L.; Said, M.Y.; Kifugo, S.C. Valuing ecosystem services for conservation and development purposes: A case study from Kenya. Environ. Sci. Policy 2013, 31, 23-33. [CrossRef]

36. Peskin, H.M. A national accounting framework for environmental assets. J. Environ. Econ. Manag. 1976, 2, 255-262. [CrossRef]

37. United Nations (UN). System of Environmental Economic Accounting for Water; United Nations: New York, NY, USA, 2012; p. 216.

38. System of Environmental-Economic Accounting for Energy (SEEA-Energy) Prepared under the Auspices of the United Nations Committee of Experts Environmental-Economic Accounting; United Nations Statistics Division (UNSD), United Nations Department of Economic and Social Affairs (DESA): New York, NY, USA, 2015; p. 174.

39. Favretto, N.; Stringer, L.C.; Dougill, A.J.; Dallimer, M.; Perkins, J.S.; Reed, M.S.; Atlhopheng, J.R.; Mulale, K. Multi-Criteria Decision Analysis to identify dryland ecosystem service trade-offs under different rangeland land uses. Ecosyst. Serv. 2016, 17, 142-151. [CrossRef] 
40. Favretto, N.; Luedeling, E.; Stringer, L.C.; Dougill, A.J. Valuing Ecosystem Services in Semi-arid Rangelands through Stochastic Simulation. Land Degrad. Dev. 2017, 28, 65-73. [CrossRef]

41. Reed, M.S.; Stringer, L.C.; Dougill, A.J.; Perkins, J.S.; Atlhopheng, J.R.; Mulale, K.; Favretto, N. Reorienting land degradation towards sustainable land management: Linking sustainable livelihoods with ecosystem services in rangeland systems. J. Environ. Manag. 2015, 151, 472-485. [CrossRef] [PubMed]

42. Hanley, N.; Barbier, E.B.; Barbier, E. Pricing Nature: Cost-Benefit Analysis and Environmental Policy; Edward Elgar: Cheltenham, UK, 2009.

43. Costanza, R.; d'Arge, R.; DeGroot, R.S.; Farber, S.; Grasso, M.; Hannon, B.; Limburg, K.; Naeem, S.; O'Neill, R.V.; Paruel, J.; et al. The value of the world's ecosystem service and natural capital. Nature 1997, 387, 253-260. [CrossRef]

44. Emerton, L. Environmental Planning and Management in Eastern Africa.; International Union for Conservation of Nature (IUCN)—The World Conservation Union, Eastern Africa Regional Office: Nairobi, Kenya, 1999.

45. The Economics of Ecosystems and Biodiversity Ecological and Economic Foundations; Kumar, P. (Ed.) Earthscan: London, UK; Washington, DC, USA, 2010; p. 133.

46. de Groot, R.; Brander, L.; van der Ploeg, S.; Costanza, R.; Bernard, F.; Braat, L.; Christie, M.; Crossman, N.; Ghermandi, A.; Hein, L.; et al. Global estimates of the value of ecosystems and their services in monetary units. Ecosyst. Serv. 2012, 1, 50-61. [CrossRef]

47. King-Okumu, C. A Framework to Assess Returns on Investments in the Dryland Systems of Northern Kenya; International Institute for Environment and Development (IIED): London, UK, 2015.

48. King-Okumu, C.; Wasonga, O.V.; Jarso, I.; Salah, Y.M.S. Direct Use Values of Climate-Dependent Ecosystem Services in Isiolo County, Kenya; International Institute for Environment and Development (IIED): London, UK, 2016.

49. King-Okumu, C. Distilling the Value of Water Investments; International Institute for Environment and Development (IIED): London, UK, 2016; p. 2.

50. King-Okumu, C.; Diop, D. Economic Valuation of Benefits from Adaptation Investments: A Methodological Note for Assessment of Returns on Locally Determined Investments in Adaptation to Climate Extremes in the Senegalese Region of Kaffrine [Evaluation économique des bénéfices de l'adaptation: Note Méthodologique pour évaluer la valeur du retour sur les investissements localement déterminés pour s'adapter aux extrêmes climatiques dans la Région de Kaffrine au Ferlo du Sénégall; International Institute for Environment and Development (IIED): London, IK, 2017; p. 70.

51. King-Okumu, C.; Diop, D.; McPeak, J. Approche d'evaluation des retours sur investissements des projets d'adaptation au changement climatiqe a Kaffrine. AGRIDAPES Revue de L'agriculture Durable a Faibles Apports Externes, 1 February 2018; Spécial DFC. 43-47.

52. Coulibaly, B.; King-Okumu, C.; Keita, A. Analyse preliminaire des incidences socio-economiques des projets de renforcement de la resilience a Mopti. AGRIDAPES Revue de L'agriculture Durable a Faibles Apports Externes, 1 February 2018; Spécial DFC. 39-42.

53. The Government of Kenya (GoK). Submission in the Area of Ecosystems, Interrelated Areas Such as Water Resources and Adaptation under the Nairobi Work Programme; NEMA (National Environment Management Authority)/National Drought Management Authority (NDMA)/The Adaptation (ADA) Consortium: Nairobi, Kenya, 2017; p. 6.

54. Adaptation Planning, Implementation and Evaluation Addressing Ecosystems and Areas Such as Water Resources-Synthesis Report by the Secretariat; The United Nations Framework Convention on Climate Change (UNFCCC): Bonn, Germany, 2017; p. 33.

55. World Atlas of Desertification; Cherlet, M., Hutchinson, C., Reynolds, J., Hill, J., Sommer, S., von Maltitz, G., Eds.; Publication Office of the European Union, Joint Research Centre (JRC): Luxembourg, Germany, 2018; p. 248.

56. World Overview of Conservation Approaches and Technologies (WOCAT). Sustainable Rangeland Management in Sub-Saharan Africa-Guidelines to Good Practice; World Overview of Conservation Approaches and Technologies: Bern, Germany, 2018; forthcoming.

57. Turpie, J.; Ngaga, Y.; Karanja, F. Catchment Ecosystems and Downstream Water: The Value of Water Resources in the Pangani Basin, Tanzania; The World Conservation Union, Ecosystems and Livelihoods Group Asia, International Union for Conservation of Nature (IUCN): Vientiane, Laos, 2005; p. 108. 
58. Fofana, I.; Tankari, M.; Traore, F. Economic Accounts for Agriculture and Farm Income in Senegal; International Food Policy Research Institute (IFPRI): Dakar, Senegal, 2017; p. 44.

59. Guilhem, D.; Boëtsch, G. Breastmilk or cow's milk? Production of the child's body by two liquid foster among the Fulani of Ferlo (Senegal) [Lait maternel ou lait de vache? La production du corps de l'enfant par deux liquides nourriciers chez les Peuls du Ferlo (Sénégal)]. Anthropozoologica 2017, 52, 91-101. [CrossRef]

60. Sougou, N.; Boëtsch, G. Diet and growth of young Fulani children in Widou Thiengoli (Ferlo, Senegal) [Alimentation et croissance des jeunes enfants Peuls à Widou Thiengoly (Ferlo-Sénégal)]. Bulletins et Memoires de la Societe d'Anthropologie de Paris 2016, 28, 145-154.

61. Musinga, M.; Kimenye, D.; Kivolonzi, P. The Camel Milk Industry in Kenya; Resource Mobilization Centre/SNV: Nanyuki, Kenya, 2008; p. 101.

62. Gaye, M. Tiviski Dairy: Africa's First Camel Milk Dairy Improves Livelihoods for Semi-Nomadic Herders in Mauritania; United Nations Development Programme (UNDP): New York, NY, USA, 2008.

63. Anderson, D.M.; Elliott, H.; Kochore, H.H.; Lochery, E. Camel herders, middlewomen, and urban milk bars: The commodification of camel milk in Kenya. J. East. Afr. Stud. 2012, 6, 383-404. [CrossRef]

64. Parisse, M. Developing local dairy production: The laiterie du Berger, Senegal. Field Actions Sci. Rep. (FACTS Rep.) 2012, 6.

65. Technical Report: Mapping Camel-Milk Corridors in Wajir County; Mercy Corps (MC): Nairobi, Kenya, $2017 ;$ p. 37.

66. Moussa, B.; Nkonya, E.; Meyer, S.; Kato, E.; Johnson, T.; Hawkins, J. Economics of Land Degradation and Improvement in Niger. In Economics of Land Degradation and Improvement-A Global Assessment for Sustainable Development; Nkonya, E., Mirzabaev, A., von Braun, J., Eds.; Springer: Basingstoke, UK, 2015; pp. 499-539.

67. Behnke, R.; Muthami, D. The Contribution of Livestock to the Kenyan Economy; IGAD Livestock Policy Initiative: Addis Ababa, Ethiopia, 2011; p. 62.

68. Elhadi, Y.A.M.; Wasonga, O.V. Economic and Nutritional Contribution of Camel Milk in Northern Kenya: A Field Study in Isiolo County; International Institute for Environment and Development (IIED): London, UK, 2015; p. 40.

69. Karp, L.; Pope, A. Range Management under Uncertainty. Am. J. Agric. Econ. 1984, 66, 437-446. [CrossRef]

70. Huffaker, R.; Cooper, K. Plant Succession as a Natural Range Restoration Factor in Private Livestock Enterprises. Am. J. Agric. Econ. 1995, 77, 901-913. [CrossRef]

71. Perrings, C.; Walker, B. Conservation in the Optimal Use of Rangelands. Ecol. Econ. 2004, 49, 119-128. [CrossRef]

72. Janssen, M.A.; Anderies, J.M.; Walker, B.H. Robust Strategies for Managing Rangelands with Multiple Stable Attractors. J. Environ. Econ. Manag. 2004, 47, 140-162. [CrossRef]

73. Finnoff, D.; Strong, A.; Tschirhart, J. A Bioeconomic Model of Cattle Stocking on Rangeland Threatened by Invasive Plants and Nitrogen Deposition. Am. J. Agric. Econ. 2008, 90, 1074-1090. [CrossRef]

74. Hein, L.; Metzger, M.J.; Leemans, R. The local impacts of climate change in the Ferlo, Western Sahel. Clim. Chang. 2009, 93, 465-483. [CrossRef]

75. Baumgärtner, J.; Gilioli, G.; Tikubet, G.; Gutierrez, A.P. Eco-social analysis of an East African agro-pastoral system: Management of tsetse and bovine trypanosomiasis. Ecol. Econ. 2008, 65, 125-135. [CrossRef]

76. Gutierrez, A.P.; Gilioli, G.; Baumgärtner, J. Ecosocial consequences and policy implications of disease management in East African agropastoral systems. Proc. Natl. Acad. Sci. USA 2009, 106, 13136-13141. [CrossRef] [PubMed]

77. Mulinge, W.; Gicheru, P.; Murithi, F.; Maingi, P.; Kihiu, E.; Kirui, O.K.; Mirzabaev, A. Economics of land degradation and improvement in Kenya. In Economics of Land Degradation and Improvement-A Global Assessment for Sustainable Development; International Food Policy Research Institute: Washington, DC, USA, 2015; pp. 471-498.

78. Herlocker, D.J.; Shaaban, S.B.; Wilkes, S. Range Management Handbook of Kenya; Ministry of Agriculture, Livestock Development and Marketing: Nairobi, Kenya, 1993.

79. Onduru, D.D.; Muchena, F.N. Cost-Benefit Analysis of Land Management Options in the Upper Tana, Kenya; ISRIC-World Soil Information: Wageningen, The Netherlands, 2011; p. 136.

80. FAO. Boosting Emergency Drought Response in Kenya. Available online: http://www.fao.org/resilience/ news-events/detail/en/c/1027789/ (accessed on 21 May 2018).

81. De Groot, R.S.; Blignaut, J.; Van Der Ploeg, S.; Aronson, J.; Elmqvist, T.; Farley, J. Benefits of Investing in Ecosystem Restoration. Conserv. Boil. 2013, 27, 1286-1293. [CrossRef] [PubMed] 
82. Mureithi, S.M.; Verdoodt, A.; Njoka, J.T.; Gachene, C.K.K.; Van Ranst, E. Benefits Derived from Rehabilitating a Degraded Semi-Arid Rangeland in Communal Enclosures, Kenya. Land Degrad. Dev. 2016, 27, 1853-1862. [CrossRef]

83. Portrait de la Famille de Moussa Ka, village de Maodo Peulh; Projet Décentralisation des fonds climat (DFC)/Innovation Environnement Dévéloppement (IED): Dakar, Senegal, 2017; p. 38.

84. King-Okumu, C. Adaptation to Climate Change: Economic Value and Return on Investments; International Institute for Environment and Development (IIED)/New Economics Foundation (NEF): London, UK, 2017; p. 22.

85. Tari, D.; King-Okumu, C.; Jarso, I. Strengthening Local Customary Institutions: A Case Study in Isiolo County, Northern Kenya; Ada Consortiumj: Nairobi, Kenya, 2015; p. 52.

86. Ahmed, H.; Call, D.R.; Quinlan, R.J.; Yoder, J.K. Relationships between livestock grazing practices, disease risk, and antimicrobial use among East African Agropastoralists. Environ. Dev. Econ. 2018, 23, 80-97. [CrossRef]

87. Peden, D.; Taddesse, G.; Haileslassie, A. Livestock water productivity: Implications for sub-Saharan Africa. Rangel. J. 2009, 31, 187-193. [CrossRef]

88. Amede, T.; Tarawali, S.; Peden, D. Improving water productivity in crop-livestock systems of drought-prone regions: Editorial comment. Exp. Agric. 2011, 47, 1-5. [CrossRef]

89. Mekonnen, M.M.; Hoekstra, A.Y. A global assessment of the water footprint of farm animal products. Ecosystems 2012, 15, 401-415. [CrossRef]

90. King-Okumu, C.; Wasonga, O.V.; Yimer, E. Pastoralism Pays: New Evidence from the Horn of Africa; International Institute for Environment and Development (IIED): London, UK, 2015; p. 4.

91. Venton, C. Economics of Resilience to Drought-Ethiopia Analysis; United States Agency for International Development (USAID): Washington, DC, USA, 2018; p. 47.

92. Venton, C. Economics of Resilience to Drought-Kenya Analysis; United States Agency for International Development (USAID): Washington, DC, USA, 2018; p. 43.

93. Ba, C.O.; Bishop, J.; Deme, M.; Diadhiou, H.D.; Dieng, A.B.; Diop, O.; Garzon, P.A.; Gueye, B.; Kebe, M.; Ly, O.K.; et al. Évaluation Économique des Ressources Sauvages au Sénégal-Évaluation Préliminaire des Produits Forestiers non Ligneux, de la Chasse et de la Pêche Continentale; International Union for Conservation of Nature (IUCN): Gland, Switzerland; Cambridge, UK, 2006; p. 79.

94. Inspection Régionale des Eaux et Forêts de Kaffrine Rapport Annuel 2014; Inspection Régionale des Eaux et Forêts (IREF): Kaffrine, Senegal, 2014; p. 68.

95. Kenya National Bureau of Statistics (KNBS). Economic Survey, 2018; Kenya National Bureau of Statistics: Nairobi, Kenya, 2018; p. 340.

96. Belem, M.; Saqalli, M. Development of an integrated generic model for multi-scale assessment of the impacts of agro-ecosystems on major ecosystem services in West Africa. J. Environ. Manag. 2017, 202, 117-125. [CrossRef] [PubMed]

97. Holden, S.; Shiferaw, B. Land degradation, drought and food security in a less-favoured area in the Ethiopian highlands: A bio-economic model with market imperfections. Agric. Econ. 2004, 30, 31-49. [CrossRef]

98. Holden, S.; Shiferaw, B.; Pender, J. Policy analysis for sustainable land management and food security in Ethiopia: A bioeconomic model with market imperfections. Res. Rep. Int. Food Policy Res. Inst. 2005, 140, 1-76.

99. Berger, T.; Troost, C.; Wossen, T.; Latynskiy, E.; Tesfaye, K.; Gbegbelegbe, S. Can smallholder farmers adapt to climate variability, and how effective are policy interventions? Agent-based simulation results for Ethiopia. Agric. Econ. 2017, 48, 693-706. [CrossRef]

100. Njenga, M. Banning Charcoal Isn't the Way to Go. Kenya Should Make It Sustainable; International Council for Research in Agroforestry (ICRAF): Nairobi, Kenya, 2018.

101. Weston, P.; Hong, R.; Kaboré, C.; Kull, C.A. Farmer-Managed Natural Regeneration Enhances Rural Livelihoods in Dryland West Africa. Environ. Manag. 2015, 55, 1402-1417. [CrossRef] [PubMed]

102. Njenga, M.; Karanja, N.; Munster, C.; Iiyama, M.; Neufeldt, H.; Kithinji, J.; Jamnadass, R. Charcoal production and strategies to enhance its sustainability in Kenya. Dev. Pract. 2013, 23, 359-371. [CrossRef]

103. Somda, J.; Naba, M.; Onadja, A. Economic Performance of Climate Change Adaptation Activities in the Volta Basin; International Union for Conservation of Nature (IUCN) Central and Western Africa Office: Ouagadougou, Burkina Faso, 2013; p. 40. 
104. Behnke, R.; Kerven, C. Climate Resilience, Productivity and Equity in the Drylands Counting the Costs: Replacing Pastoralism with Irrigated Agriculture in the Awash Valley, North-Eastern Ethiopia; International Institute for Environment and Development (IIED): London, UK, 2013; p. 49.

105. Niemi, E.; Manyindo, J. Economic Importance of Goods and Services Derived from Dryland Ecosystems in the IGAD Region: Case Studies; International Union for Conservation of Nature (IUCN): Nairobi, Kenya, 2010; p. 48.

106. Aboud, A.A.; Kisoyan, P.K.; Said, M.Y.; Notenbaert, A.; de Leeuw, J.; Gitau, J.W.; Manzano, P.; Davies, J.M.; Roba, G.M.; Omondi, S.O.; et al. Natural Resource Management and Biodiversity Conservation in the Drylands of Eastern and Central Africa; Association for Strengthening Agricultural Research in Eastern and Central Africa (ASARECA): Entebbe, Uganda, 2012; p. 91.

107. Barbier, E.B. Upstream dams and downstream water allocation: The case of the Hadejia-Jama'are floodplain, northern Nigeria. Water Resour. Res. 2003, 39, WES11-WES19. [CrossRef]

108. Barbier, E.B. Wetlands as natural assets [Les zones humides en tant que biens naturels]. Hydrol. Sci. J. 2011, 56, 1360-1373. [CrossRef]

109. Acharya, G.; Barbier, E.B. Valuing groundwater recharge through agricultural production in the Hadejia-Nguru wetlands in northern Nigeria. Agric. Econ. 2000, 22, 247-259. [CrossRef]

110. Acharya, G.; Barbier, E. Using domestic water analysis to value groundwater recharge in the Hadejia-Jama' are floodplain, Northern Nigeria. Am. J. Agric. Econ. 2002, 84, 415-426. [CrossRef]

111. Aich, V.; Koné, B.; Hattermann, F.F.; Paton, E.N. Time series analysis of floods across the Niger River Basin. Water 2016, 8, 165. [CrossRef]

112. Wymenga, E.; Zwarts, L.; Kone, B. Water Sharing in the Upper Niger Basin; Wetlands International, Bamako/Sévaré Mali \& Altenburg \& Wymenga Ecological Consultants: Feanwâlden, The Netherlands, 2012; p. 63.

113. The Niger, a Lifeline. Effective Water Management in the Upper Niger Basin; Zwarts, L.P., Beukering, V., Kone, B., Wymenga, E., Eds.; RIZA: Lelystad, The Netherlands; Wetlands International: Sévaré, Mali; Institute for Environmental Studies (IVM): Amsterdam, The Netherlands; A\&W Ecological Consultants: Veenwouden, The Netherlands, 2005; p. 169.

114. Morand, P.; Kodio, A.; Andrew, N.; Sinaba, F.; Lemoalle, J.; Béné, C. Vulnerability and adaptation of African rural populations to hydro-climate change: Experience from fishing communities in the Inner Niger Delta (Mali). Clim. Chang. 2012, 115, 463-483. [CrossRef]

115. Hamerlynk, O.; Duvail, S. Ecosystem restoration and livelihoods in the Senegal River Delta, Mauritania. In Linking Conservation and Poverty Reduction: Landscapes, People and Power; Fisher, R.J., Maginnis, S., Jackson, W.J., Barrow, E., Jeanrenaud, S., Eds.; Earthscan: London, UK, 2008; pp. 68-77.

116. Shine, T.; Dunford, B. What value for pastoral livelihoods? An economic valuation of development alternatives for ephemeral wetlands in eastern Mauritania. Pastor. Res. Policy Pract. 2016, 6, 18. [CrossRef]

117. Gichohi, W.H. Direct payments as a mechanism for conserving important wildlife corridor links between Nairobi National Park and its wider ecosystem: The wildlife conservation lease programme. In Proceedings of the Vth World Parks Congress, Durban, South Africa, 8-17 September 2003.

118. Silvestri, S.; Osano, P.; de Leeuw, J.; Herrero, M.; Ericksen, P.; Kariuki, J.; Njuki, J.; Bedelian, C.; Notenbaert, A. Greening Livestock: Assessing the Potential for Payment for Environmental Services in Livestock Inclusive Agricultural Production Systems in Developing Countries; International Livestock Research Institute (ILRI): Nairobi, Kenya, 2012; p. 55.

119. McGahey, D.; Davies, J.; Hagelberg, N.; Ouedraogo, R. Pastoralism and the Green Economy—A Natural Nexus? International Union for Conservation of Nature (IUCN): Gland, Switzerland; United Nations Environment Programme (UNEP): Nairobi, Kenya, 2014; p. 58.

120. Rodríguez, L.C.; Henson, D.; Herrero, M.; Nkedianye, D.; Reid, R. Private farmers' compensation and viability of protected areas: The case of Nairobi National Park and Kitengela dispersal corridor. Int. J. Sustain. Dev. World Ecol. 2012, 19, 34-43. [CrossRef]

121. Mwangi, H.M.; Lariu, P.; Julich, S.; McDonald, M.A.; Feger, K.-H. Characterizing the intensity and dynamics of land-use change in the Mara River Basin, East Africa. Forests 2017, 9, 8. [CrossRef]

122. Lingane, A.; Olsen, S. Guidelines for social return on investment. Calif. Manag. Rev. 2004, 46, 116-135. [CrossRef]

123. Nicholls, J.; Eilis, L.; Neitzert, E.; Goodspeed, T. A Guide to Social Return on Investment; The SROI Network: London, UK, 2012; p. 55. 
124. Wasike, W.S.K.; Hanley, N. The pricing of domestic water services in developing countries: A contingent valuation application to Kenya. Int. J. Water Resour. Dev. 1998, 14, 41-54. [CrossRef]

125. A Guide to the Social Return on Investment; The SROI Network, Nef: London, UK, 2012; p. 110.

126. Metaferia. Productive Safety Net Program (APL III) Final Report Consulting Services for Conducting Productive Safety Net Program 2nd 2011 Public Works Impact Assessment Credit\#: 4666-ET; Metaferia Consulting Engineers: Addis Ababa, Ethiopia, 2013; p. 128.

127. Hutton, G. Benefits and Costs of the Water Sanitation and Hygiene Targets for the Post-2015 Development Agenda-Working Paper as of 26 January, 2015; World Bank/Copenhagen Consensus Center: Copenhagen, Denmark, 2015; p. 32.

128. Luedeling, E.; Oord, A.L.; Kiteme, B.; Ogalleh, S.; Malesu, M.; Shepherd, K.D.; Leeuw, J.D. Fresh groundwater for Wajir-Ex-ante assessment of uncertain benefits for multiple stakeholders in a water supply project in Northern Kenya. Front. Environ. Sci. 2015, 3, 16. [CrossRef]

129. Ndirangu, W. Catalysing Low Cost Green Technologies for Sustainable Water Service Delivery in Kenya-Feasibility Study Report; Climate Technology Centre and Network (CTCN), The UN Environment Programme (UNEP), Technical University of Denmark (DTU) \& Water Services Trust Fund (WSTF): Nairobi, Kenya, 2017; p. 147.

130. Mwaura, J.; Koske, J.; Kiprotich, B. Economic value of water harvesting for climate-smart adaptation in semi-arid Ijara Garissa, Kenya. Environ. Syst. Res. 2018, 6, 10. [CrossRef]

131. O’Farrell, P.J.; De Lange, W.J.; Le Maitre, D.C.; Reyers, B.; Blignaut, J.N.; Milton, S.J.; Atkinson, D.; Egoh, B.; Maherry, A.; Colvin, C.; et al. The possibilities and pitfalls presented by a pragmatic approach to ecosystem service valuation in an arid biodiversity hotspot. J. Arid. Environ. 2011, 75, 612-623. [CrossRef]

132. Hassan, R.M.; Okbrich, B. Comparative analysis of the economic efficiency of water use by plantation forestry and irrigation agriculture in the Crocodile catchment. Agrekon 1999, 38, 566-575. [CrossRef]

133. Lange, G.-M.; Mungatana, E.; Hassan, R.M. Water accounting for the Orange River Basin: An economic perspective on managing a transboundary resource. Ecol. Econ. 2007, 6, 660-670. [CrossRef]

134. Bouma, J.A.; Hegde, S.S.; Lasage, R. Assessing the returns to water harvesting: A meta-analysis. Agric. Water Manag. 2016, 163, 100-109. [CrossRef]

135. Rebelo, L.-M.; McCartney, M.P.; Finlayson, C.M. Wetlands of Sub-Saharan Africa: Distribution and contribution of agriculture to livelihoods. Wetl. Ecol. Manag. 2010, 18, 557-572. [CrossRef]

136. Nieuwoudt, W.L.; Backeberg, G.R.; Du Plessis, H.M. The value of water in the South African economy: Some implications. Agrekon 2004, 43, 162-183. [CrossRef]

137. Crafford, J.G.; Hassan, R.M.; King, N.A.; Damon, M.C.; de Wit, M.P.; Bekker, S.; Rapholo, B.M.; Olbrich, B.W. An Analysis of the Social, Economic, and Environmental Direct and Indirect Costs and Benefits of Water Use in Irrigated Agriculture and Forestry; Water Research Commission: Pretoria, South Africa, 2004.

138. Moolman, C.E.; Blignaut, J.N.; Van Eyden, R. Modelling the marginal revenue of water in selected agricultural commodities: A panel data approach. Agrekon 2006, 45, 78-88. [CrossRef]

139. Mutiga, J.K.; Mavengano, S.T.; Zhongbo, S.; Woldai, T.; Becht, R. Water Allocation as a Planning Tool to Minimise Water Use Conflicts in the Upper Ewaso Ng'iro North Basin, Kenya. Water Resour. Manag. 2010, 24, 3939-3959. [CrossRef]

140. Stockholm Environment Institute (SEI). WEAP: Water Evaluation and Planning System, User Guide for WEAP21; Stockholm Environment Institute: Boston, MA, USA, 2001.

141. Kenya: Post-Disaster Needs Assessment (PDNA) for the 2008-2011 Drought; Republic of Kenya with Technical Support from the European Union, United Nations, and World Bank and Financial Support from the European Union and the Grand Duchy of Luxembourg; Republic of Kenya: Nairobi, Kenya, 2012; p. 188.

142. Gies, L.; Agusdinata, D.B.; Merwade, V. Drought adaptation policy development and assessment in East Africa using hydrologic and system dynamics modeling. Nat. Hazards 2014, 74, 789-813. [CrossRef]

143. Agusdinata, D.B. Evaluating water infrastructure and agriculture practices for drought adaptations in East Africa: A combined hydrological and system dynamics approach. In Proceedings of the GHTC 2016-IEEE Global Humanitarian Technology Conference: Technology for the Benefit of Humanity, Conference Proceedings 7857362, Seattle, DC, USA, 13-16 October 2016; pp. 753-760.

144. Blignaut, J.; Mander, M.; Schulze, R.; Horan, M.; Dickens, C.; Pringle, C.; Mavundla, K.; Mahlangu, I.; Wilson, A.; McKenzie, M.; et al. Restoring and managing natural capital towards fostering economic development: Evidence from the Drakensberg, South Africa. Ecol. Econ. 2010, 69, 1313-1323. [CrossRef] 
145. Ashagre, B.B.; Platts, P.J.; Njana, M.; Burgess, N.D.; Balmford, A.; Turner, R.K.; Schaafsma, M. Integrated modelling for economic valuation of the role of forests and woodlands in drinking water provision to two African cities. Ecosyst. Serv. 2018, 32, 50-61. [CrossRef]

146. Turpie, J.K.; Forsythe, K.J.; Knowles, A.; Blignaut, J.; Letley, G. Mapping and valuation of South Africa's ecosystem services: A local perspective. Ecosyst. Serv. 2017, 27, 179-192. [CrossRef]

147. Emerton, L. Local-Level Investments in Natural Water Infrastructure: Economic Preferences, Constraints and Incentives for Sustainable Land Management among Farmers in the Upper Tana Basin, Kenya; BC3 Report for the WISE UP Project; International Union for Conservation of Nature (IUCN): Leioa, Spain, 2017; p. 31.

148. The Economics of Ecosystem Services of the Tana River Basin Assessment of the Impact of Large Infrastructural Interventions; Beukering, P.V., de Moel, H., Eds.; Institute for Environmental Studies (IVM)/The Economics of Ecosystems and Biodiversity (TEEB): Amsterdam, The Netherlands, 2015; p. 163.

149. Emerton, L. Case Studies in Wetland Valuation \#6: May 2003 Tana River, Kenya: Integrating Downstream Values into Hydropower Planning; International Union for Conservation of Nature (IUCN): Nairobi, Kenya, 2003; p. 6.

150. Apse, C.; Bryant, B.; Droogers, P.; Hunink, J.; Kihara, F.; Leisher, C.; Vogl, A.; Wolny, S. Upper Tana-Nairobi Water Fund A Business Case; Natural Capital Project and FutureWater; The Nature Conservancy: Washington, DC, USA, 2014; p. 36.

151. Vogl, A.L.; Bryant, B.P.; Hunink, J.E.; Wolny, S.; Apse, C.; Droogers, P. Valuing investments in sustainable land management in the Upper Tana River basin, Kenya. J. Environ. Manag. 2017, 195, 78-91. [CrossRef] [PubMed]

152. Upper Tana-Nairobi Water Fund (UTNWF) Detailed Design Report; International Fund for Agricultural Development (IFAD): Rome, Italy, 2017; p. 56.

153. Schmiedel, U.; Kruspe, M.; Kayser, L.; Oettlé, N. The Ecological and Financial Impact of Soil Erosion and its Control-A Case Study from the Semiarid Northern Cape Province, South Africa. Land Degrad. Dev. 2017, 28, 74-82. [CrossRef]

154. Yoo, J.; Simonit, S.; Connors, J.P.; Maliszewski, J.P.; Kinzig, A.P.; Perrings, C. The value of agricultural water rights in agricultural properties in the path of development. Ecol. Econ. 2013, 91, 57-68. [CrossRef]

155. Choumert, J.; Stage, J.; Uwera, C. Access to water as determinant of rental values: A housing hedonic analysis in Rwanda. J. Hous. Econ. 2015, 26, 48-54. [CrossRef]

156. Freeman, A.M., III. Hedonic prices, property values and measuring environmental benefits: A survey of the issues. Scand. J. Econ. 1979, 81, 154-173. [CrossRef]

157. Miyata, Y.; Abe, H. Measuring the Effects of a Flood Control Project: Hedonic Land Price Approach. J. Environ. Manag. 1994, 42, 389-401. [CrossRef]

158. Yoo, J.; Simonit, S.; Connors, J.P.; Kinzig, A.P.; Perrings, C. The valuation of off-site ecosystem service flows: Deforestation, erosion and the amenity value of lakes in Prescott, Arizona. Ecol. Econ. 2014, 97, 74-83. [CrossRef]

159. Poor, P.J.; Pessagno, K.L.; Paul, R.W. Exploring the hedonic value of ambient water quality: A local watershed-based study. Ecol. Econ. 2007, 60, 797-806. [CrossRef]

160. Daniel, V.E.; Florax, R.J.G.M.; Rietveld, P. Flooding risk and housing values: An economic assessment of environmental hazard. Ecol. Econ. 2009, 69, 355-365. [CrossRef]

161. Gulyani, S.; Talukdar, D.; Bassett, E.M. A sharing economy? Unpacking demand and living conditions in the urban housing market in Kenya. World Dev. 2018, 109, 57-72. [CrossRef]

162. Brozovic, N.; Sunding, D.L.; Zilberman, D. On the Spatial Nature of the Groundwater Pumping Externality. Resour. Energy Econ. 2010, 32, 154-164. [CrossRef]

163. Epanchin-Niell, R.; Kuwayama, Y.; Walls, M. Spatial-dynamic complexities of climate challange for rural areas: Integrating resource and regional economic insights. Am. J. Agric. Econ. 2017, 99, 447-463. [CrossRef]

164. Speir, C.; Han, J.; Brozovic, N. Spatial Dynamic Optimization of Groundwater Use with Ecological Standards for Instream Flow. Water Econ. Policy 2016, 2. [CrossRef]

165. Saak, A.E.; Peterson, J.M. Groundwater Use under Incomplete Information. J. Environ. Econ. Manag. 2007, 54, 214-228. [CrossRef]

166. Athanassoglou, S.; Sheriff, G.; Siegfried, T.; Huh, W.T. Optimal Mechanisms for Heterogeneous Multi-Cell Aquifers. Environ. Resour. Econ. 2012, 52, 265-291. [CrossRef] 
167. Sahle, M.; Saito, O.; Fürst, C.; Demissew, S.; Yeshitela, K. Future land use management effects on ecosystem services under different scenarios in the Wabe River catchment of Gurage Mountain chain landscape, Ethiopia. Sustain. Sci. 2018, 1-16. [CrossRef]

168. Sahle, M.; Saito, O.; Fürst, C.; Yeshitela, K. Quantifying and mapping of water-related ecosystem services for enhancing the security of the food-water-energy nexus in tropical data-sparse catchment. Sci. Total Environ. 2019, 646, 573-586. [CrossRef] [PubMed]

169. Sharp, R.; Tallis, H.T.; Ricketts, T.; Guerry, A.D.; Wood, S.A.; Chaplin-Kramer, R.; Nelson, E.; Ennaanay, D.; Wolny, S.; Olwero, N.; et al. VEST + VERSION + User's Guide; The Natural Capital Project; Stanford University, University of Minnesota, The Nature Conservancy and World Wildlife Fund: Stanford, CA, USA, 2015.

170. Tallis, H.T.; Ricketts, T.; Guerry, A.D.; Wood, S.A.; Sharp, R.; Nelson, E.; Ennaanay, D.; Wolny, S.; Olwero, N.; Vigerstol, K.; et al. VEST 2.2.1 User's Guide; The Natural Capital Project; Stanford University: Stanford, CA, USA, 2011.

171. Belete, M.; Deng, J.; Zhou, M.; Wang, K.; You, S.; Hong, Y.; Weston, M. A new approach to modelingwater balance in Nile River Basin, Africa. Sustainability 2018, 10, 810. [CrossRef]

172. Rukundo, E.; Liu, S.; Dong, Y.; Rutebukaa, E.; Asamoah, E.F.; Xu, J.; Wu, X. Spatio-temporal dynamics of critical ecosystem services in response to agricultural expansion in Rwanda, East Africa. Ecol. Indic. 2018, 89, 696-705. [CrossRef]

173. Leh, M.D.K.; Matlock, M.D.; Cummings, E.C.; Nalley, L.L. Quantifying and mapping multiple ecosystem services change in West Africa. Agric. Ecosyst. Environ. 2013, 165, 6-18. [CrossRef]

174. Duku, C.; Rathjens, H.; Zwart, S.J.; Hein, L. Towards ecosystem accounting: A comprehensive approach to modelling multiple hydrological ecosystem services. Hydrol. Earth Syst. Sci. 2015 19, 4377-4396.

(C) 2018 by the author. Licensee MDPI, Basel, Switzerland. This article is an open access article distributed under the terms and conditions of the Creative Commons Attribution (CC BY) license (http:/ / creativecommons.org/licenses/by/4.0/). 